\title{
ANÁLISE PALINOLÓGICA DA VEREDA DA FAZENDA URBANO, MUNICÍPIO DE BURITIZEIRO, MINAS GERAIS, BRASIL
}

\author{
Flávio Lima Lorente ${ }^{1}$; Karin Elise Bohns Meyer²; Adolf Heinrich Horn² \\ RESUMO

\begin{abstract}
Mudanças paleoambientais e paleoecológicas a partir do final do Pleistoceno em Buritizeiro (MG) foram interpretadas com base na análise palinológica de um perfil sedimentar amostrado na vereda da Fazenda Urbano. A análise palinológica foi realizada em sete amostras sedimentares ao longo de $60 \mathrm{~cm}$ de uma fácies silto-argilosa com matéria orgânica, datada na base em 13.120 \pm 60 anos AP, e consistiu de duas etapas, uma qualitativa, onde foram identificados 51 palinomorfos; e uma quantitativa, cujos resultados foram expressos em formas de diagramas de concentração e porcentagem. A identificação e a contagem dos palinomorfos permitiram caracterizar duas palinozonas (FZU 1 e FZU 2), que refletem variações nos padrões de umidade e na dinâmica da vegetação na região. A palinozona FZU 1 (13.120 \pm 60 a $11.640 \pm 60$ anos AP) foi caracterizada pelo predomínio de grãos de pólen de elementos arbustivos-herbáceos, pela rara ocorrência de grãos de pólen de elementos arbóreos e pela ausência de Mauritia flexuosa, sugerindo que formações campestres semelhantes à fitofisionomia Campo Limpo ocupavam a região sob condições climáticas mais secas do que as atuais. Na palinozona FZU 2 (6.000 - idade interpolada a $1.500 \pm 40$ anos AP) foi observado o aumento de grãos de pólen de elementos arbóreos e na diversidade dos táxons arbustivo-herbáceos e arbóreos, além da substituição do tipo fitofisionômico Campo Limpo por um mosaico das fitofisionomias Campo Sujo e Cerrado sentido restrito, e do estabelecimento da vereda sob condições climáticas mais úmidas, semelhantes e/ou comparáveis às condições climáticas atuais da região.
\end{abstract} \\ Palavras chave: Palinologia, Quaternário, Cerrado, Minas Gerais, vereda
}

\begin{abstract}
Palaeoenvironmental and palaeoecological changes since the late Pleistocene in Buritizeiro (MG) were interpreted based on pollen analysis of a sedimentary profile collected in a palm swamp from Fazenda Urbano. The pollen analysis was performed in seven sedimentary samples along $60 \mathrm{~cm}$ of a silt-clay facies with organic matter, dated on the basis of $13.120 \pm 60$ years BP. It was consisted of two steps, a qualitative, whereby 51 palynomorphs were identified; and a quantitative, being the results expressed through concentration and percentage diagrams. The identification and the counting of palynomorphs characterized two palinozones (FZU 1 and FZU 2) that reflect variations in moisture patterns and vegetation dynamics in the region. The palinozone FZU $1(13,120 \pm 60$ to $11,640 \pm 60$ years BP) was characterized by the predominance of shrubs and herbs pollen, by the rare occurrence of tree pollen grains and by the absence of Mauritia flexuosa, suggesting that grassland formations similar to Campo Limpo vegetation occupied the region under climate conditions that were drier than today. In palinozone FZU 2 (6.000 - interpolated age to $1.500 \pm 40$ years BP) it was observed an increase in tree pollen grains and in the diversity of shrubby-herbaceous and trees taxa, besides the replacement of Campo Limpo vegetation by a mosaic of Campo Sujo and Cerrado sensu stricto vegetation types and the establishment of the palm swamp under wetter climate conditions, similar and / or comparable to current weather conditions in the region.

Keywords: Palynology, Quaternary, Cerrado, Minas Gerais, palm swamp.
\end{abstract}

\section{INTRODUÇ̃̃̃O}

A palinologia de sedimentos quaternários pode ser um importante parâmetro para a compreensão e reconstituição das condições ambientais ao longo do tempo. As variações climáticas durante o Quaternário, principalmente no Último Máximo Glacial (UMG), influenciaram a evolução da fauna e flora mundial, com reflexos significativos nos ecossistemas brasileiros, tais como o Cerrado.

O Cerrado constitui o segundo maior bioma em área do Brasil, apresentando em sua paisagem inclusões de formações florestais em meio às formações campestres e savânicas (Ferreira, 1980). Dentre os diversos tipos fitofisionômicos do Cerrado, existem as veredas, que são depressões abertas e rasas, formadas por dois tipos de vegetação: uma herbáceo-graminosa que ocupa a maior parte de sua área, e outra arbóreo-arbustiva com predominância de buritis (Carvalho, 1991). Os solos destas formações contêm bons depósitos de sedimentos finos ricos em matéria orgânica, grãos de pólen e esporos e, portanto, são utilizados nas análises palinológicas (Salgado-Labouriau, 1997).

Apesar da importância das veredas para o Cerrado, ainda existem poucos estudos sobre este tipo fitofisionômico, principalmente em Minas Gerais. Neste contexto, a análise palinológica da vereda da Fazenda Urbano acrescenta dados para a interpretação paleoclimática e paleoecológica do Quaternário em Minas Gerais, e mais especificamente no contexto da

1 - Programa de Pós-graduação em Geologia, Universidade Federal de Minas Gerais, Av. Antônio Carlos,

6.627, 31270-901, Belo Horizonte, Minas Gerais, Brasil. flimalorente@yahoo.com.br

2 - CPMTC-IGC, Universidade Federal de Minas Gerais, Av. Antônio Carlos, 6.627, 31270-901,

Belo Horizonte, Minas Gerais, Brasil.

bohnsmeyer@yahoo.com.br, hahorn@ufmg.br. 
evolução paleoambiental do bioma Cerrado na área da Sub-bacia do Rio do Formoso, no Alto Vale da Bacia do Rio São Francisco.

\section{ÁREA DE ESTUDO E CONTEXTO GEOLÓGICO}

A área de estudo está localizada na Sub-bacia do Rio do Formoso, município de Buritizeiro, região norte do estado de Minas Gerais (figura 1). O município está situado a $364 \mathrm{~km}$ da capital mineira, Belo Horizonte, e sua superfície de $7.236 \mathrm{~km}^{2}$ encontra-se a 910 metros de altitude no Chapadão dos Gerais.

O clima na região, segundo a classificação de Köppen, é do tipo Aw, ou seja, tropical chuvoso, com verão chuvoso e inverno seco, mas devido ao alto déficit hídrico durante três meses do ano, o clima tende ao semi-árido (Embrapa, 2008). A vegetação que caracteriza a região é predominantemente composta por fitofisionomias do bioma Cerrado, além de áreas de reflorestamento com Pinus sp. e Eucaliptus sp (IEF, 2008).

A vereda da Fazenda Urbano está depositada sobre rochas pré-cambrianas do Grupo Bambuí, na parte meridional da Bacia Sanfranciscana. Esta bacia, intracratônica do tipo Depressão Interior (Kingston et al., 1983), possui forma alongada e ocupa uma área de $500.000 \mathrm{~km}^{2}$, abrangendo parte dos estados de Minas Gerais, Goiás, Bahia e Tocantins, tendo limites com as Bacias do Paraná e Parnaíba, e com as bordas externas das faixas Brasília e Araçuaí (Alkmin \& Martins-Neto, 2001).

A Formação Três Marias é a única formação do Grupo Bambuí ocorrente na Sub-bacia do Rio do Formoso, ocupando o entorno dos planaltos areníticos, aflorando nos patamares, bordas ravinadas, vales encaixados e também no assoalho do Rio São Francisco e alguns de seus afluentes, constituindo-se de arcósios e siltitos (Melo, 2008).

As unidades cretáceas aflorantes na Sub-bacia do Rio do Formoso são referentes ao Grupo Areado (Formação Abaeté e Três Barras) e ao Grupo Mata da Corda (Formação Patos e Capacete). Os arenitos eólicos estão distribuídos de forma descontínua dentro da bacia e localmente constituem platôs, topos planos e podem estar recobertos por níveis de lateritas ferruginosas. Em discordância erosiva com os arenitos do Grupo Areado, encontram-se depositadas rochas vulcanoclásticas, conglomerados e arenitos epiclásticos, gerando na morfologia uma seqüência de morrotes alinhados preferencialmente na direção SW-NE, e declividade acentuada em direção aos fundos dos vales. As coberturas cenozóicas da Sub-bacia do Rio Formoso são predominantemente arenosas, estando associadas à planície de inundação das drenagens e ao retrabalhamento fluvial recente, estando os sedimentos distribuídos amplamente ao longo dos principais cursos d'água que drenam a região (Baggio, 2008).

\section{MATERIAL E MÉTODOS}

\section{LEVANTAMENTO FLORÍSTICO}

O levantamento da cobertura vegetal atual na vereda da Fazenda Urbano foi realizado com o intuito de registrar as espécies vegetais que ocorrem atualmente no local de amostragem, e comparar com as espécies identificadas no registro polínico. As espécies vegetais foram coletadas ao longo de um transecto de $60 \mathrm{~m}$ nos estratos herbáceo-arbustivo e arbóreo da vereda. Após a coleta, o materia botânico foi herborizado e identificado no Laboratório de Sistemática Vegetal do Instituto de Ciências Biológicas, da Universidade Federal de Minas Gerais.

\section{AMOSTRAGEM E DATAÇÃO PELO MÉTODO DE C14}

Para a amostragem, foi realizada a abertura de uma trincheira com profundidade de 1,20 $\mathrm{m}$ na zona encharcada da vereda da Fazenda Urbano $\left(17^{\circ} 24^{\prime} 25^{\prime}, \mathrm{S} / 45^{\circ} 03^{\prime} 33^{\prime} \mathrm{W}\right)$, no município de Buritizeiro, Minas Gerais. As sete amostras utilizadas na preparação palinológica foram coletadas diretamente no perfil sedimentar da trincheira em intervalos não superiores a $10 \mathrm{~cm}$ (Ybert et al., 1992) e de acordo com a seqüência estratigráfica, da base para o topo (figura 2). Após a retirada das amostras sedimentares, os sedimentos do perfil aflorante foram descritos quanto à granulometria, coloração e aspectos macroscópicos, tais como a presença de restos vegetais, como raízes e radículas de plantas.

As datações das amostras pelo método de C14 foram realizadas no Beta Analytic Inc. Lab., Miami, Flórida, EUA, através do método de Espectometria de Massa com Aceleradores (accelerator mass spectometry $A M S$ ). A partir das datações radiocarbônicas foi possível calcular as taxas de sedimentação (cm/100 anos) entre os níveis estratigráficos datados e conseqüentemente interpolar as idades entre estes.

\section{PROCESSAMENTO DAS AMOSTRAS E ANÁLISE PALINOLÓGICA}

O processamento químico das amostras sedimentares foi realizado no Laboratório de Palinologia do Centro de Pesquisa Professor Manoel Teixeira da Costa (CPMTC), IGC-UFMG, com base no procedimento palinológico padrão descrito por Faegri \& Iversen (1989) e as lâminas montadas em gelatina glicerinada. Para a determinação da concentração polínica (grãos/ $\mathrm{cm}^{3}$ ) foi adicionado $1 \mathrm{mg}$ do marcador exótico Kochia scoparia, com aproximadamente 60.583 grãos por mg, ao sedimento de cada nível (Salgado-Labouriau \& Rull, 1986).

A identificação dos palinomorfos foi feita através de comparação com material polínico disponível na 


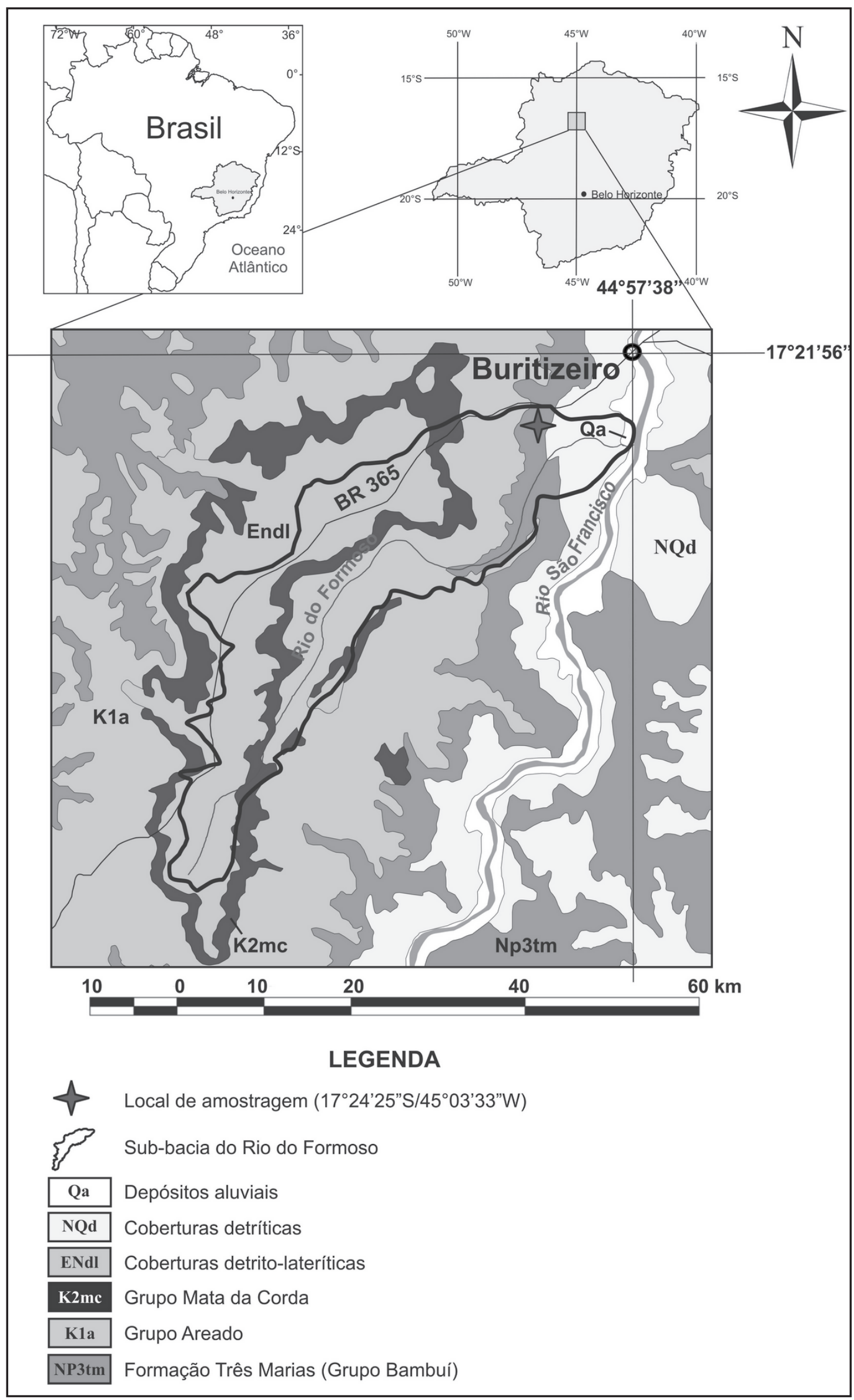

Figura 1. Mapa de localização da vereda da Fazenda Urbano (modificado de Heineck et al., 2003). 


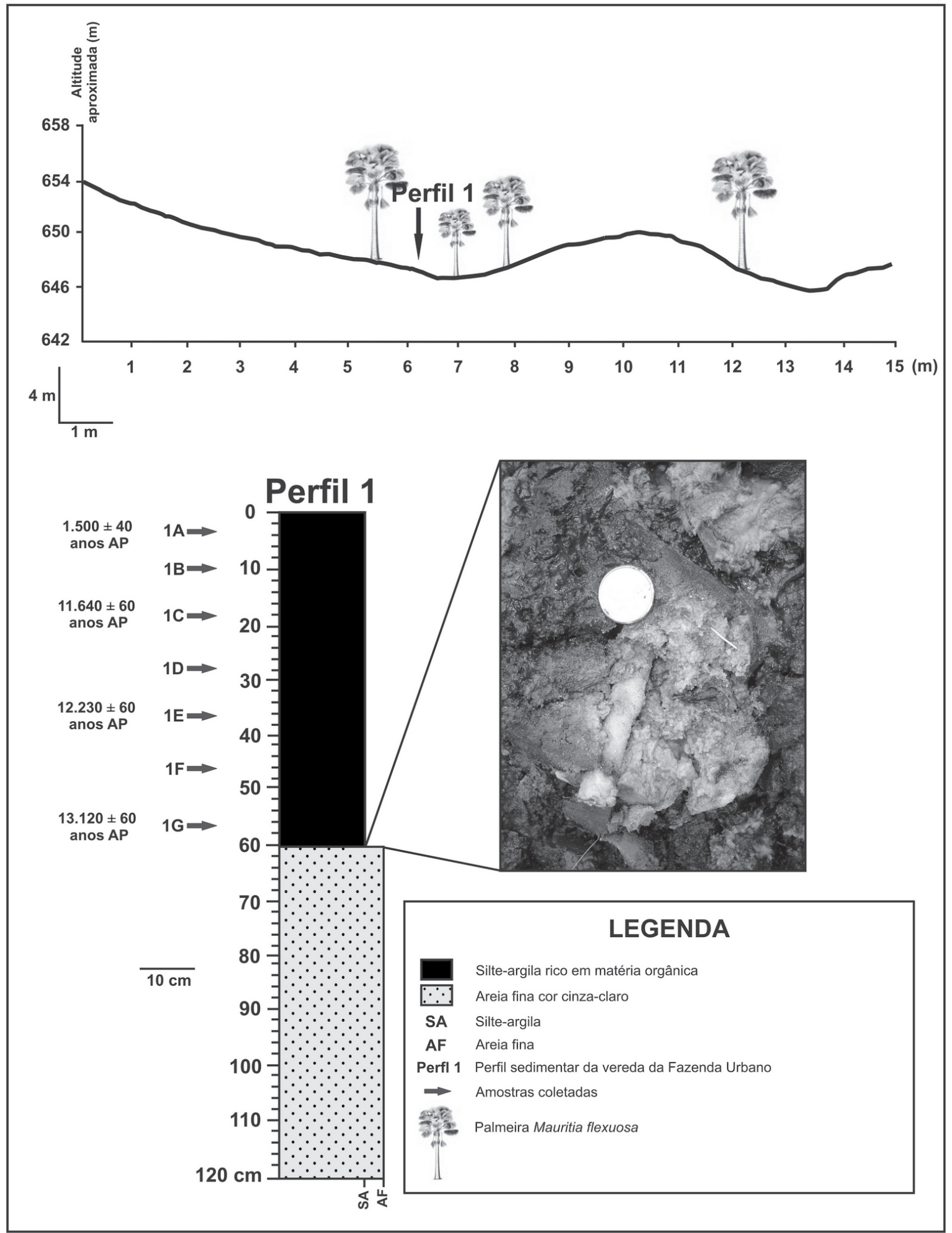

Figura 2. Perfil sedimentar da vereda da Fazenda Urbano e posicionamento das amostras nos níveis amostrados.

Palinoteca de Referência do Laboratório de Palinologia do CPMTC, IGC-UFMG, e com base na literatura especializada, destacando-se os trabalhos de SalgadoLabouriau (1973), Van Geel (1978), Tryon \& Tryon (1982), Colinvaux et al. (1999), Bauermann (2003) e Silva (2009).

A análise quantitativa foi realizada em microscopia de luz transmitida, sob o aumento de 600x. Foram contados no mínimo 500 grãos de pólen, incluindo os tipos arbóreos, arbustivos e herbáceos e lianas. Paralelamente a este número mínimo de grãos de pólen, foram contados os esporos de pteridófitos, algas, fungos e o marcador exótico Kochia scoparia.

Os fitoclastos opacos, denominação da análise de palinofácies, ou charcoal e, ou partículas de carvão, como são conhecidos estes componentes orgânicos 
Tabela 1. Cronologia radiocarbônica das amostras sedimentares da vereda da Fazenda Urbano.

\begin{tabular}{ccccc}
\hline $\begin{array}{c}\text { Amostra/ } \\
\text { Profundidade }(\mathrm{cm})\end{array}$ & $\begin{array}{c}\text { Código do } \\
\text { laboratório }\end{array}$ & $\begin{array}{c}\text { Idade } \\
\text { convencional } \\
\text { (anos A.P) }\end{array}$ & ${ }^{13} \mathrm{C} /{ }^{12} \mathrm{C}$ & $\begin{array}{c}\text { Taxa de } \\
\text { sedimentação } \\
\text { (cm/100 anos) }\end{array}$ \\
\hline 1A $(6-0)$ & Beta 276187 & $1.500 \pm 40$ & -18.7 & 0,15 \\
$1 B(21-17)$ & Beta 273522 & $11.640 \pm 60$ & -15.4 & 3,0 \\
$1 \mathrm{E}(39-34)$ & Beta 273521 & $12.230 \pm 60$ & -16.6 & 2,3 \\
$1 \mathrm{C}(60-54)$ & Beta 269831 & $13.120 \pm 60$ & -16.4 & \\
\hline
\end{tabular}

particulados nos trabalhos de análise palinológica, não foram considerados neste trabalho para inferir incêndios naturais ou antrópicos, por ter sido utilizada a centrifugação durante a preparação palinológica. Tyson (1995) afirma que os fitoclastos opacos são muito secos e quebradiços e que o uso de centrífuga na preparação palinológica pode quebrar estas partículas aumentando com isto seu número nas amostras estudadas.

Os resultados da análise qualitativa e quantitativa dos palinomorfos foram sintetizados em forma de diagramas de concentração e porcentagem elaborados pelos programas Tilia, Tilia GView 2.0.2 e CONISS (Grimm, 1987). O CONISS cria os agrupamentos pelo índice de similaridade, desta forma, o significado ambiental dos táxons dos agrupamentos gerados foi utilizado na interpretação das variações da paleovegetação na vereda da Fazenda Urbano.

\section{RESULTADOS}

\section{LEVANTAMENTO FLORÍSTICO}

O levantamento da cobertura vegetal atual na vereda da Fazenda Urbano resultou na identificação dos seguintes táxons: Poaceae (Panicum L., Urochloa P.Beauv.), Malpighiaceae (Byrsonima sericea DC.), Asteraceae (Emilia sonchifolia (L.)DC., Elephantopus mollis Kunth., Bidens gardineri Baker., Mikania micrantha Kunth., Vernonia brasiliana Druce.), Fabaceae (Vigna Savi., Calliandra Kenth.), Melastomataceae (Tibouchina Aubl.), Lamiaceae (Hyptis Jacq.), Lythraceae (Cuphea P.Browne), Myrtaceae (Campomanesia Ruiz \& Pav.), Onagraceae (Ludwigia L.), Rubiaceae (Borreria verticillata (L.)G.Mey.), Malvaceae (Pavonia Cav., Sida L., Malachra L.), Solanaceae (Solanum palinacanthuam Dunal.), Campanulaceae (Lobelia camporum Pohl.), Pteridaceae (Pityrogramma calomelanus (L.)Link.) e Thelypteridaceae (Thelypteris salzmannii (Fée) C.V.Morton).

\section{PERFIL SEDIMENTAR}

O perfil recuperado na vereda da Fazenda Urbano foi caracterizado por duas fácies. A fácies da base (120 $-60 \mathrm{~cm}$ ) é composta de areia fina, coloração cinzaclaro, com pouca matéria orgânica. A fácies do topo $(60-0 \mathrm{~cm})$ apresentou sedimentos de granulometria silte-argila, coloração preta, com grande quantidade de matéria orgânica e restos vegetais, como folhas, raízes e radículas de plantas.

\section{DATAÇÕES RADIOCARBÔNICAS}

As datações radiocarbônicas pelo método de espectometria de acelerador de massa (AMS) foram realizadas em quatro amostras sedimentares ao longo do perfil. As idades dos níveis datados e as taxas de sedimentação estão apresentadas na tabela 1 .

A partir das datações radiocarbônicas ficou evidenciado que a taxa de sedimentação na vereda da Fazenda Urbano foi muito baixa e que os sedimentos que representam o intervalo de tempo de $1.500 \pm 40$ anos aos dias de hoje foi erodido.

\section{ANÁLISE PALINOLÓGICA}

A análise palinológica consistiu de duas etapas, uma qualitativa, onde foram identificados 51 palinomorfos, e uma quantitativa, cujos resultados foram expressos em formas de diagramas de concentração e porcentagem elaborados pelos programas Tilia e Tilia GView 2.0.2 (Grimm, 1987). Os gráficos apresentam ainda uma análise de agrupamentos realizada pelo programa CONISS, que permitiu o estabelecimento de duas palinozonas, denominadas da base para o topo de FZU 1 (A e B) e FZU 2.

Os resultados da análise qualitativa e quantitativa do perfil sedimentar da vereda da Fazenda Urbano estão sintetizados nas figuras de 3 a 6 .

\section{PALINOZONA FZU $1(60$ - 17 CM)}

A palinozona FZU 1 foi caracterizada com base na análise palinológica de cinco amostras da fácies 


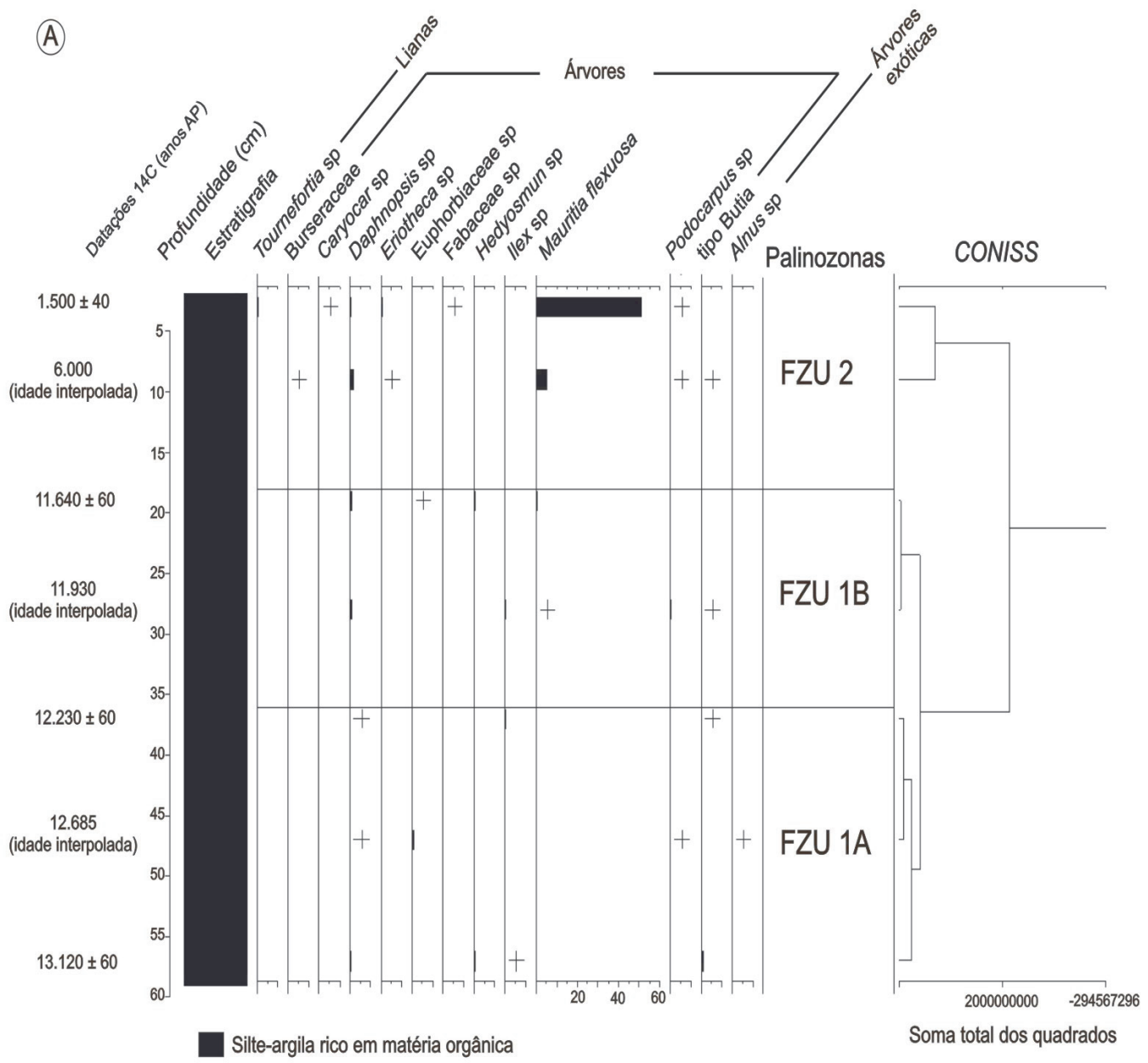

(B)

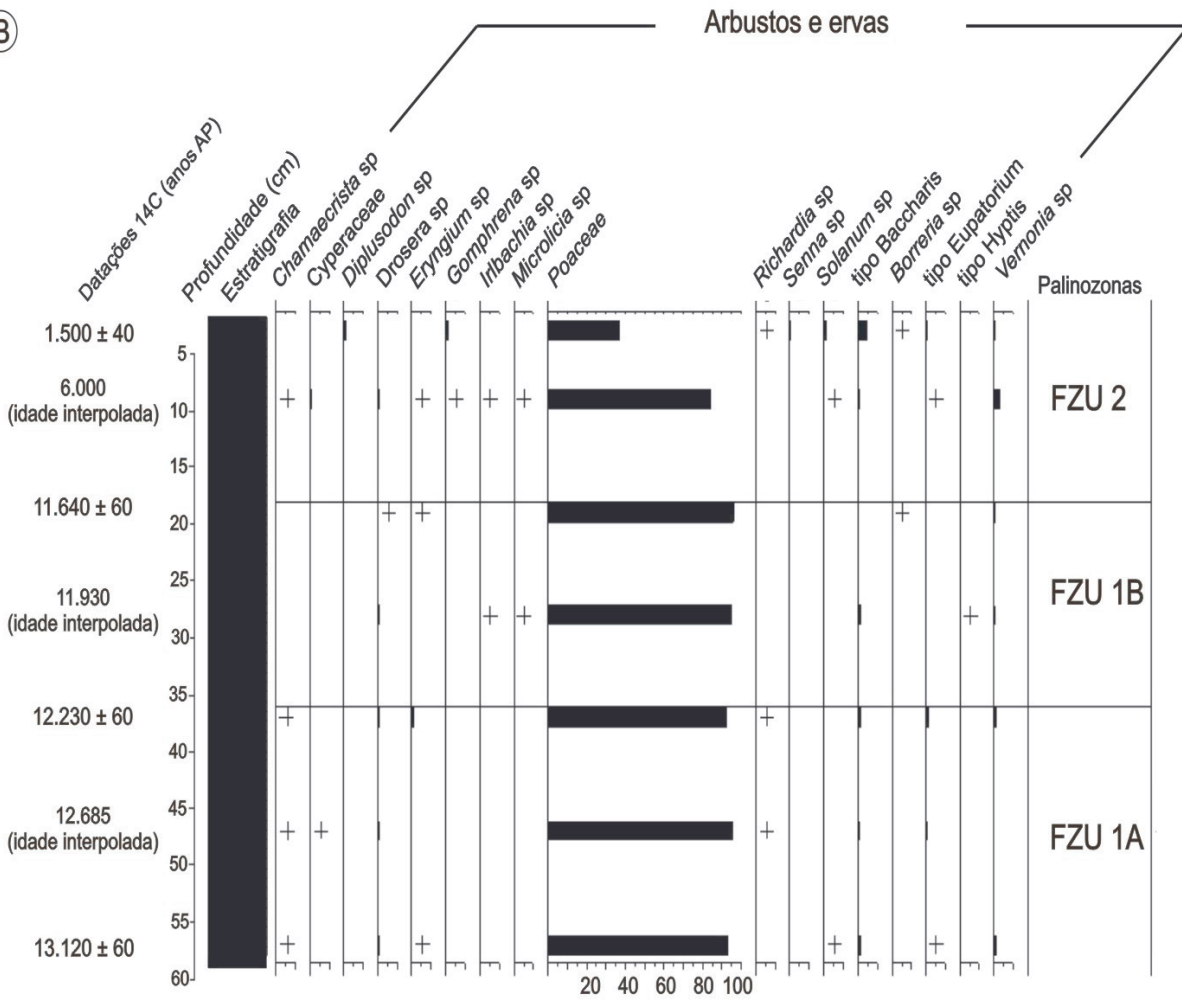

Silte-argila rico em matéria orgânica

Figura 3. Diagrama palinológico de porcentagem. A, lianas, árvores e árvores exóticas; B, arbustos e ervas. 
silto-argilosa, e corresponde ao intervalo de tempo de $13.120 \pm 60$ a $11.640 \pm 60$ anos AP. A análise de agrupamento permitiu a separação desta palinozona em duas subzonas, FZU 1A, entre 60 e 34 cm, e FZU $1 \mathrm{~B}$, entre 30 e $17 \mathrm{~cm}$.

\section{1 - Subzona FZU 1A $(60-34 \mathrm{~cm})$}

A subzona FZU 1A compreende três amostras da base do perfil, com idade variando de $13.120 \pm 60$ a $12.230 \pm 60$ anos AP.

Nesta subzona ocorreu o predomínio de grãos de pólen de elementos arbustivos e herbáceos (98\%), seguidos pelos zigósporos de algas que apresentaram uma média de $14,4 \%$, esporos de pteridófitos $(4,2 \%)$, fungos $(1,5 \%)$ e em menor porcentagem, os elementos arbóreos $(1,4 \%)$.

Dentre os elementos arbustivos e herbáceos, Poaceae é o táxon predominante, com média de $93 \%$. Ervas e arbustos das famílias Asteraceae $(1,4 \%)$, Rubiaceae $(0,5 \%)$ e Cyperaceae $(0,2 \%)$, e os gêneros do tipo Hyptis (0,8\%), Drosera $(0,4 \%)$, Chamaecrista $(0,2 \%)$, Eryngium $(0,2-0,8 \%)$ e Solanum $(0,2 \%)$ também são registrados nesta subzona (figura 3).

Os elementos arbóreos apresentaram baixos valores percentuais, com a ocorrência dos táxons tipo Butia (0,2-1\%), Hedyosmum (0,6\%), Daphnopsis (0,2\%), Ilex (0,2- 0,6\%) e Podocarpus (0,2\%). Cabe ressaltar que o grão de pólen da árvore exótica Alnus teve sua ocorrência única ao longo de todo o perfil, ocorrendo pontualmente no intervalo entre 44 e $50 \mathrm{~cm}$ (figura 3).

Dentre os pteridófitos ocorrentes, Blechnum (0,6-3\%) e Lycopodiella alopecuroides (0,8-1,8\%) foram predominantes (figura 4). Com registros escassos e/ou com índices percentuais menores que $1 \%$ podem ser destacados os seguintes táxons: Lycopodiella caroliniana $(0,4-0,8 \%)$, Cyatheaceae $(0,4 \%)$, Lycopodium clavatum $(0,4 \%)$, Polypodium $(0,2 \%)$ e Schizaea $(0,2 \%)$.

As algas são representadas principalmente por Debarya (6,2-10\%) e Chlamydomonas (1,8-4,4\%), seguidas por Zygnema, Mougeotia, Pseudoschizaea rubina e Botryococcus braunii com valores abaixo de $1 \%$ (figura 4).

O diagrama de concentração mostrou valores altos de concentração dos palinomorfos arbustivos e herbáceos, sobretudo Poaceae. Os grãos de pólen de Asteraceae, Chamaecrista, Drosera, tipo Richardia e Borreria também estiveram bem representados, com os seus valores de concentração em média entre 100 e 500 grãos $/ \mathrm{cm}^{3}$. O tipo Eupatorium e o tipo Hyptis apresentaram pico de concentração na profundidade entre 44 e $50 \mathrm{~cm}$, com 800 e 400 grãos/ $\mathrm{cm}^{3}$ respectivamente (figura 5 ).

Dentre os elementos arbóreos, Daphnopsis e tipo Butia tiveram picos de concentração de até 300 grãos $/ \mathrm{cm}^{3}$ na base da subzona (figura 5), e dentre os pteridófitos, o táxon Lycopodiella alopecuroides apresentou os maiores valores de concentração, com média de 500 esporos $/ \mathrm{cm}^{3}$. Os zigósporos de algas estiveram bem representados e diversificados nesta subzona. Os táxons Chlamydomonas e Debarya apresentaram média de 1.500 e 4.000 zigósporos $/ \mathrm{cm}^{3}$ respectivamente (figura 6 ).

2 - FZU 1B (34 - $17 \mathrm{~cm})$

A subzona FZU 1B, corresponde ao intervalo de tempo de $12.230 \pm 60$ a $11.640 \pm 60$ anos AP, e foi caracterizada com base na análise palinológica de duas amostras.

A subzona FZU 1B apresentou a composição palinológica semelhante à subzona FZU 1A, com o predomínio de grãos de pólen de elementos arbustivos e herbáceos (97\%), seguidos pelos zigósporos de algas ( $9 \%$ ), esporos de pteridófitos $(3,9 \%)$, elementos arbóreos $(2,2 \%)$, e em menor porcentagem os fungos $(1,6 \%)$. No entanto, o que diferiu esta subzona da FZU 1A foi o pequeno aumento $(0,8 \%)$ dos elementos arbóreos com o aparecimento da palmeira Mauritia flexuosa no topo da subzona, e o declínio das algas $(5,4 \%)$ entre 30 e 26 $\mathrm{cm}$, o que corresponde a aproximadamente 11.930 anos AP (idade interpolada).

Dentre os elementos arbustivos e herbáceos, Poaceae continuou predominante (95\%), e as ervas da família Asteraceae, Vernonia $(0,8 \%)$ e tipo Baccharis $(0,8 \%)$, tiveram um decréscimo no topo da subzona. Os grãos de pólen de Borreria, tipo Eupatorium, Irlbachia, Microlicia, tipo Hyptis e Drosera ocorreram com valores percentuais abaixo de $0,5 \%$ (figura 3 ).

Dentre os táxons arbóreos, tipo Butia, Daphnopsis, Hedyosmun, Podocarpus e Ilex permaneceram com valores semelhantes ao da subzona anterior, entre 0,4 e $0,8 \%$. Cabe ressaltar, que no topo da subzona ( 11.640 \pm 60 anos AP), apareceu pela primeira vez no registro o grão de pólen de Mauritia flexuosa, com o valor percentual de $1 \%$ (figura 3 ).

Os pteridófitos estiveram representados principalmente pelo Blechnum $(2,2 \%)$, seguido dos esporos de Lycopodiella caroliniana (1,4-1,6\%), Lycopodiella alopecuroides (0,2-1,2\%) e Cyatheaceae $(0,6 \%)$. Os esporos de Polypodium e Lycopodiella cernua aparecem pontualmente com $0,2 \%$ cada (figura 4).

Dentre as algas, Debarya (3,6-4\%), Mougeotia (13,8\%) e Chlamydomonas (1,6-2,4\%) são predominantes, e os zigósporos de Zygnema e Pseudoschizeae rubina ocorrem com valores percentuais inferiores a $1 \%$. Os fungos aparecem com média de 1,6\%, tendo sido registrado nesta subzona o aparecimento do esporo do gênero Glomus com 0,2\% (figura 4).

No diagrama polínico de concentração foi observado o predomínio de Poaceae, alcançando 500.000 grãos/ $\mathrm{cm}^{3}$ na base da subzona, e dos táxons tipo Baccharis e Drosera com valores de concentração semelhantes ao da subzona anterior (figura 5). Outros elementos arbustivos e herbáceos tiveram sua concentração reduzida ou não apareceram na subzona.

Os elementos arbóreos como Daphnopsis, Ilex, Hedyosmum e Podocarpus apareceram com valores em média de 400 grãos $/ \mathrm{cm}^{3}$ (figura 5). Dentre os pteridófitos, Lycopodiella alopecuroides e Lycopodiella caroliniana 
(A)

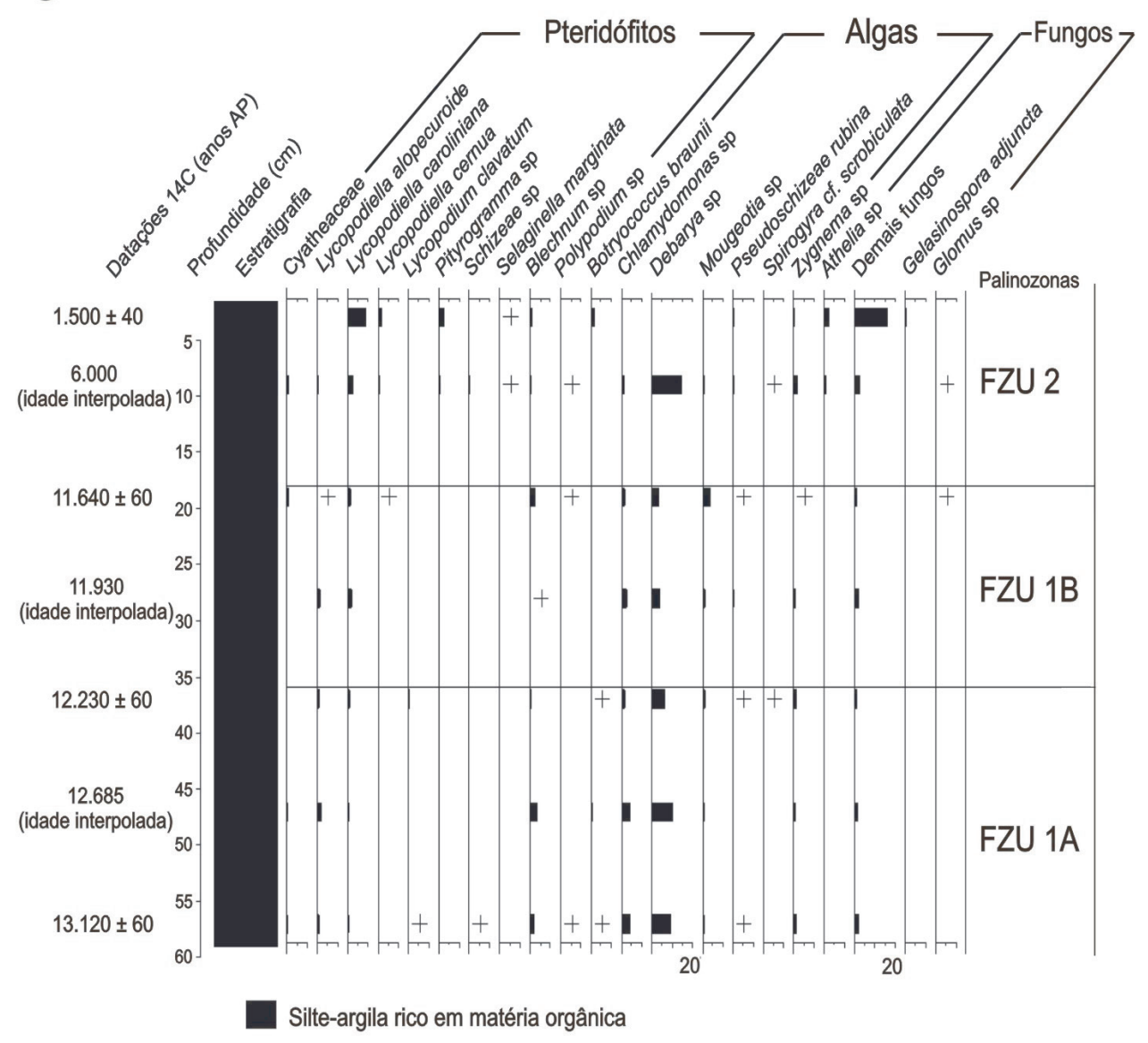

(B)

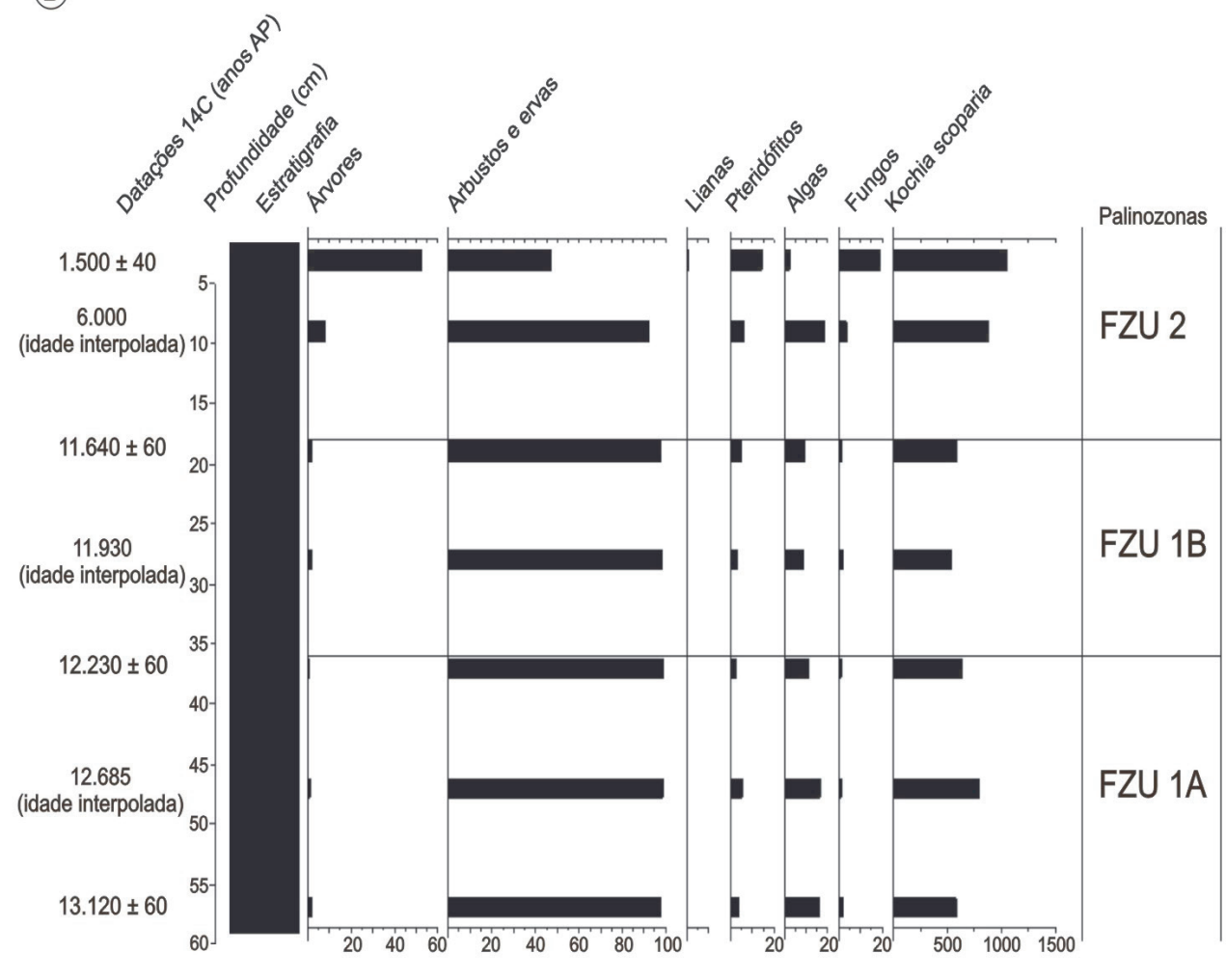

Silte-argila rico em matéria orgânica

Figura 4. Diagrama palinológico de porcentagem.

$A$, pteridófitos, algas e fungos; $B$, porcentagem total dos palinomorfos. 
(A)
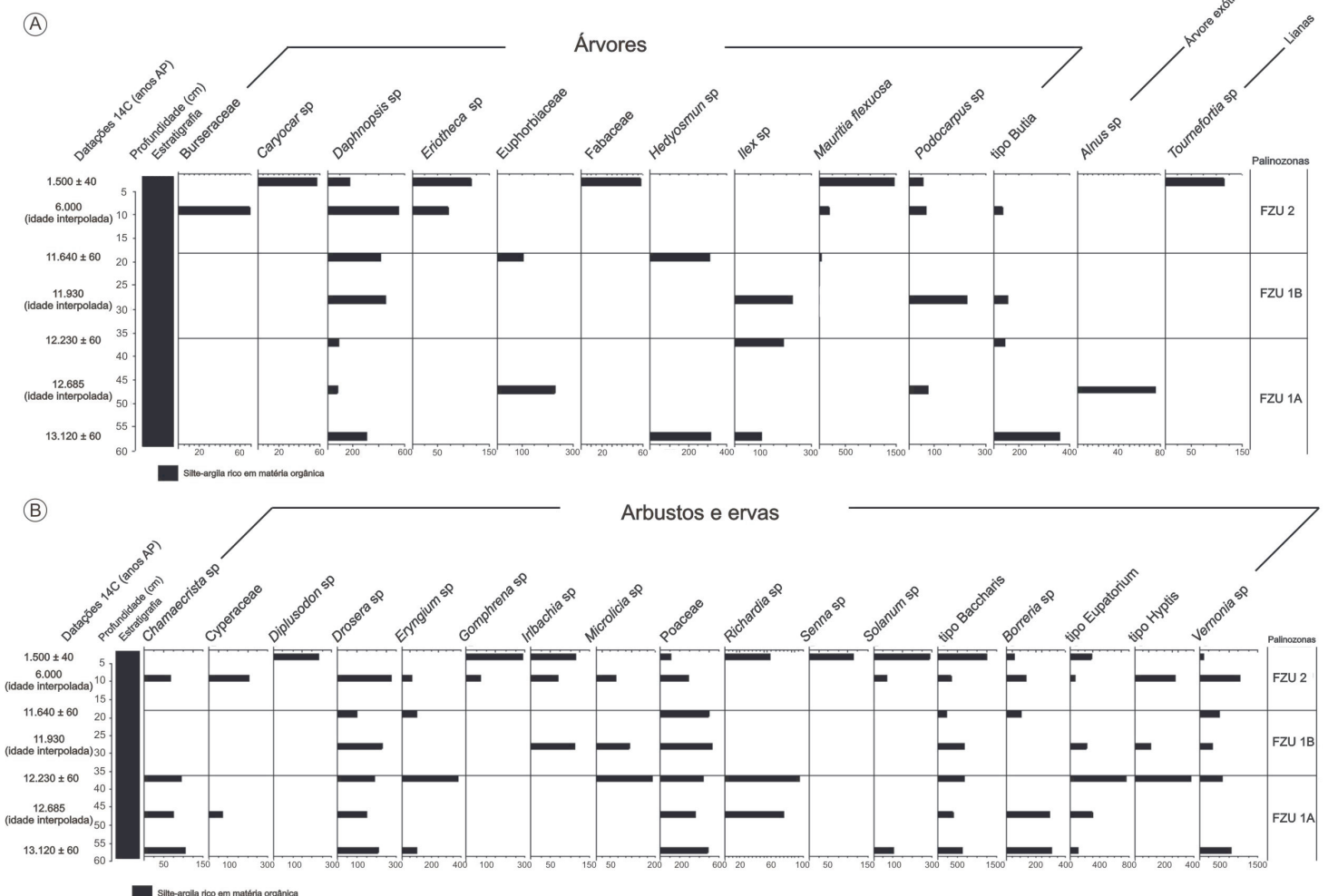

Figura 5. Diagrama palinológico de concentração.

$A$, árvores, árvores exóticas e lianas; $B$, arbustos e ervas.

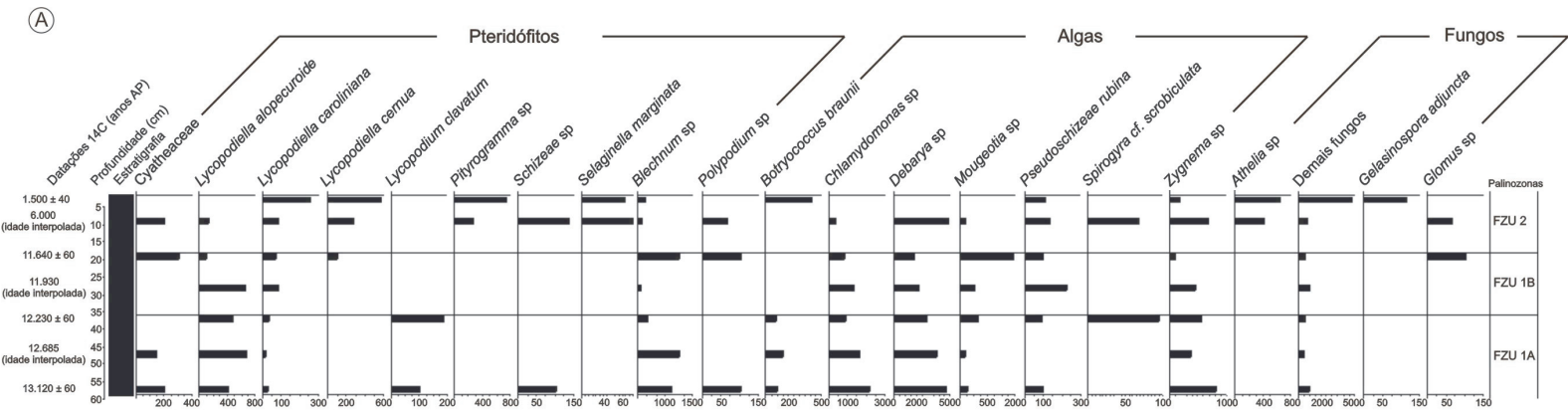

(B)

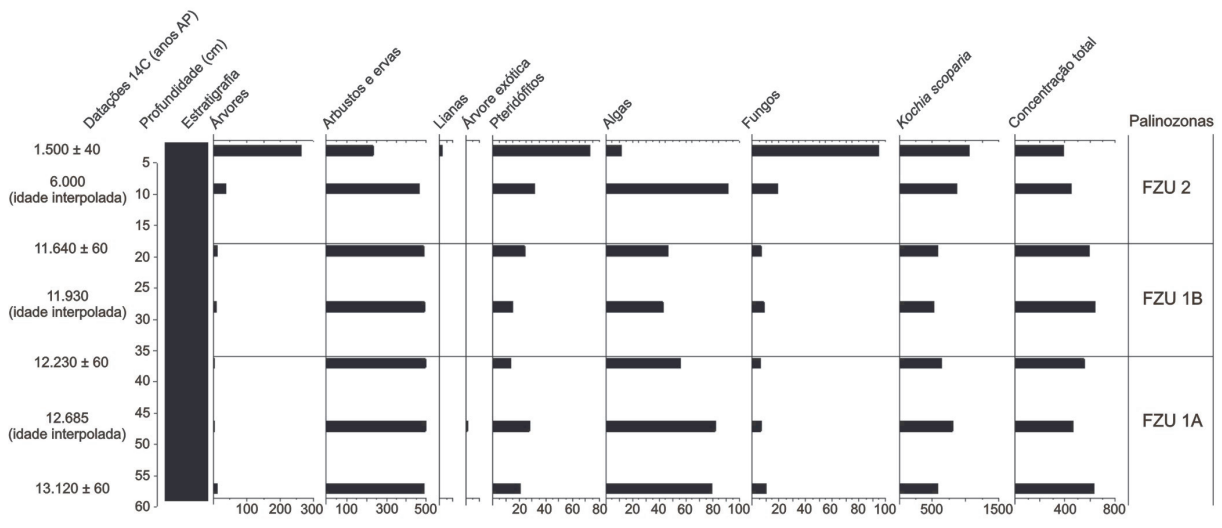

- Silte-argila rico em matéria orgânica

Figura 6. Diagrama palinológico de concentração.

$A$, pteridófitos, algas e fungos; $B$, concentração total dos palinomorfos. 
apresentaram um decréscimo de concentração em direção ao topo da subzona, e o esporo de Blechnum, ao contrário, apresentou um aumento de sua concentração entre 21 e $17 \mathrm{~cm}$, alcançando cerca de 1.250 esporos/ $\mathrm{cm}^{3}$ (figura 6).

As algas tiveram um declínio nos valores de concentração nesta subzona, em relação à FZU 1A, e os fungos mantiveram seus valores de concentração constantes.

\section{PALINOZONA FZU 2 (17 - 0 CM)}

A palinozona FZU 2 foi caracterizada com base na análise palinológica de duas amostras do topo da fácies silto-argilosa do perfil, correspondendo ao intervalo de tempo de 6.000 (idade interpolada) a $1.500 \pm 40$ anos AP.

Os grãos de pólen de elementos arbustivos e herbáceos $(70 \%)$ continuaram predominantes, mas apresentaram uma diminuição percentual, em contraste com o aumento dos grãos de pólen de elementos arbóreos (30,2\%). Os fungos também tiveram um aumento em sua representatividade com relação à outra palinozona do perfil, com média de $23 \%$. Os pteridófitos $(10,5 \%)$, as algas $(10,4 \%)$ e as lianas $(0,4 \%)$ completam os palinomorfos dos táxons registrados neste intervalo.

De modo geral, foi observado que os elementos arbustivos e herbáceos diminuíram em valores percentuais, quando comparados aos demais intervalos do perfil, no entanto, houve um aumento na diversidade destes táxons com o aparecimento de novos gêneros. Ervas das famílias Poaceae e Asteraceae (tipo Baccharis, 2,7\% e Vernonia, 1,7\%) continuaram predominantes, no entanto o táxon Poaceae alcançou no topo da palinozona seu menor valor percentual ao longo de todo o perfil, com $37,2 \%$ (figura 3 ).

Com registros pontuais e/ou com índices percentuais menores que $1 \%$, pode-se destacar os seguintes táxons: tipo Hyptis, Drosera, tipo Eupatorium, Solanum, Cyperaceae, Borreria, Irlbachia, Microlicia, Richardia, Chamaecrista e Eryngium. Os gêneros Diplusodon $(0,8 \%)$, Senna $(0,4 \%)$, Gomphrena $(0,2 \%)$, e a liana Tournefortia $(0,2 \%)$ apareceram unicamente nesta palinozona (figura 3).

Os elementos arbóreos apresentaram um aumento em sua representatividade, dentre estes o registro da palmeira Mauritia flexuosa, que no intervalo de 6 a $0 \mathrm{~cm}(1.500 \pm 40$ anos AP), alcançou 51\% no total destes elementos. Dentre os elementos arbóreos, Daphnopsis foi registrado com valor percentual de $1,1 \%$, valor este semelhante ao encontrado na palinozona FZU 1, e os táxons tipo Butia e Podocarpus ocorreram pontualmente. Além dos elementos arbóreos anteriormente registrados, os táxons Burseraceae, Fabaceae e as árvores típicas de Cerrado, Eriotheca e Caryocar, apareceram somente nesta palinozona, com valores inferiores a $0,5 \%$ (figura 3 ).

Os percentuais de esporos de pteridófitos aumentaram em direção ao topo do perfil sedimentar, alcançando o maior valor percentual ao longo de toda a seqüência sedimentar $(15 \%)$. Os esporos de Lycopodiella caroliniana (2,6-9\%), Pityrogramma (0,8-2,6\%) e Lycopodiella cernua $(0,2-2 \%)$ foram predominantes. Com valores percentuais menores que $1 \%$, foram registrados os esporos de Lycopodiella alopecuroides, Cyatheaceae, Blechnum, Selaginella marginata e Polypodium. Cabe ressaltar o aparecimento dos pteridófitos Pityrogramma e Selaginella marginata no perfil (figura 4 ).

As algas apresentaram altos valores percentuais no intervalo entre 11 e $7 \mathrm{~cm}$, no entanto, diminuem em representatividade em direção ao topo do perfil. Os zigósporos de Debarya (14,2\%), Zygnema (0,6$2 \%$ ) Botryococcus (1,4\%) foram predominantes, seguidos por Chlamydomonas (1\%), Mougeotia (0,6\%), Spirogyra cf. scrobiculata $(0,4 \%)$ e Pseudoschizaea rubina $(0,4 \%)$. Os fungos foram representados por esporos de Athelia (1,2-2,2\%), Glomus (0,2\%) e outros esporos indeterminados, alcançando no topo da palinozona o maior valor percentual ao longo de todo o perfil, com 16,4\% (figura 4).

No diagrama de concentração, pode-se observar o aumento significativo da representatividade dos elementos arbóreos, com a palmeira Mauritia flexuosa alcançando um pico de 1.500 grãos $/ \mathrm{cm}^{3}$. A árvore Daphnopsis também esteve bem representada, e os táxons de Cerrado, Eriotheca e Caryocar, foram registrados com valores de concentração em média de 60 grãos $/ \mathrm{cm}^{3}$ (figura 5 ).

Dentre os elementos arbustivos e herbáceos, Poaceae permaneceu predominante, mas com declínio em direção ao topo. Os arbustos e as ervas Drosera, Gomphrena, Solanum e tipo Baccharis registraram nesta palinozona, picos de concentração acima de 200 grãos $/ \mathrm{cm}^{3}$ (figura 5).

Os pteridófitos e fungos tiveram um aumento em suas representatividades em direção ao topo com valores de concentração de até 70.000 e 90.000 esporos $/ \mathrm{cm}^{3}$ respectivamente, e as algas, ao contrário, declinaram, registrando sua menor concentração do perfil, com cerca de 10.000 zigósporos $/ \mathrm{cm}^{3}$ (figura 6).

\section{DISCUSSÃO E INTERPRETAÇÃO PALEOAMBIENTAL}

A análise palinológica do perfil sedimentar da vereda da Fazenda Urbano permitiu estabelecer duas palinozonas, que mostram em linhas gerais que houve uma transição de condições climáticas mais secas que as atuais durante o final do Pleistoceno para condições de maior umidade após 6.000 anos AP (idade interpolada), e que a vegetação esteve influenciada por fatores como a disponibilidade hídrica e a estacionalidade climática.

Esta análise palinológica, aliada às datações radiocarbônicas, possibilitou a reconstituição paleoambiental e paleoecológica da área estudada e sua correlação com dados palinológicos de outras regiões do Cerrado brasileiro a partir do final do Pleistoceno, mais 
especificamente no intervalo de tempo compreendido entre $13.120 \pm 60$ e $1.500 \pm 40$ anos AP.

\section{PALINOZONA FZU 1 (A E B)}

No período entre $13.120 \pm 60$ e $11.640 \pm 60$ anos AP, a área estudada foi caracterizada pelo predomínio de elementos arbustivos e herbáceos, representados principalmente pelos táxons Poaceae, Asteraceae (tipo Baccharis, tipo Eupatorium e Vernonia) e Rubiaceae (Borreria e Richardia), que ocorrem preferencialmente em vegetação de campo, em áreas com dossel aberto, bem iluminadas e com vegetação menos densa (Marchant et al., 2002; Souza \& Lorenzi, 2005). Além de ervas e arbustos comuns em campos, os táxons de locais úmidos e/ou alagados (Drosera, Cyperaceae, Eryngium, tipo Hyptis) também foram registrados na seqüência sedimentar durante este período.

O predomínio dos elementos arbustivos e herbáceos sugeriu que no local estudado existiam grandes áreas de campos dominadas por gramíneas, semelhante ao tipo fitofisionômico Campo Limpo, que ocorre atualmente no bioma Cerrado. Este tipo fitofisionômico é uma formação campestre predominantemente herbácea, com raros arbustos e ausência de árvores, sendo comumente encontrado nas chapadas, circundando veredas e nas bordas de Mata de Galeria. Além disso, esta fitofisionomia apresenta variações determinadas pela umidade do solo, podendo ser classificado em Campo Limpo Seco ou Campo Limpo Úmido (Ribeiro \& Walter, 2008).

Os elementos arbóreos estiveram infra-representados ou ocorreram pontualmente na palinozona FZU 1, tendo sido registrados os táxons Daphnopsis, Hedyosmun, Podocarpus, Ilex, Euphorbiaceae e tipo Butia. As árvores registradas nesta palinozona são descritas atualmente como ocorrentes em diversos tipos de habitats, desde formações campestres até formações florestais do bioma Cerrado (Mendonça et al., 2008).

Os táxons Ilex, Hedyosmum e Podocarpus são muitas vezes associados nos registros polínicos do Quaternário como ocorrentes em fases com condições climáticas mais frias do que as atuais. No entanto, a rara ocorrência destes elementos arbóreos ao longo de todo o perfil sedimentar, associada ao fato de que atualmente são descritas espécies destes táxons em fitofisionomias do bioma Cerrado, como matas de galeria e áreas alagáveis (Mendonça et al., 2008), não permite o estabelecimento de uma correlação com a diminuição da temperatura no intervalo estudado.

O predomínio de elementos de formações campestres entre $13.120 \pm 60$ e $11.640 \pm 60$ anos AP e a ocorrência de grãos de pólen de Mauritia flexuosa somente em $11.640 \pm 60$ anos AP sugerem que as condições ambientais durante o final do Pleistoceno eram mais secas na região. A influência do último período glacial, que terminou há cerca de 12.000 anos AP, ocasionou a diminuição da quantidade de água presente na atmosfera e conseqüentemente no índice de chuvas nas áreas continentais (Salgado-Labouriau, 1994).

A escassez de chuvas provavelmente resultou na diminuição do nível do lençol freático e dos cursos d'água na região de Buritizeiro. Embora a umidade tenha permanecido em áreas de depressões da região, fato evidenciado pela ocorrência de grãos de pólen de ervas de locais úmidos e de zigósporos de algas na palinozona FZU 1, a umidade não foi suficiente para o estabelecimento da fitofisionomia de vereda e para o desenvolvimento da Mauritia flexuosa. Para que esta palmeira ocupe e cresça em determinado local, é necessário que o clima seja quente e úmido, com valores de precipitação superiores a $1.000 \mathrm{~mm}$ anuais e solos permanentemente úmidos (González, 1987).

A precipitação pluviométrica média atual para o bioma Cerrado é de 1.200 a $1.800 \mathrm{~mm}$ anuais, com variações entre 600 e $800 \mathrm{~mm}$ no limite com a Caatinga e entre 2.000 e $2.200 \mathrm{~mm}$ na interface com a Amazônia (Reatto \& Martins, 2001). É possível que os níveis de precipitação pluviométrica para a região de Buritizeiro durante o final do Pleistoceno fossem semelhantes e/ ou comparáveis aos que ocorrem nas áreas de limite do Cerrado com a Caatinga, onde os períodos de estiagem e déficit hídrico têm duração de sete a oito meses.

Embora a ausência de Mauritia flexuosa no registro polínico até $11.640 \pm 60$ anos AP tenha maior relação com a diminuição da umidade durante este período, é possível que a média de temperatura na região de Buritizeiro também fosse mais baixa, sendo um fator inibidor para o desenvolvimento desta espécie que atualmente não se expande a latitudes superiores a $20^{\circ} \mathrm{S}$ (Lorenzi, 1996). No entanto, os táxons descritos nos registros polínicos como ocorrentes em áreas de temperaturas baixas como Ilex, Hedyosmum e Podocarpus estiveram infra-representados ou ocorreram apenas pontualmente no perfil da vereda da Fazenda Urbano, além do fato de que grãos de pólen de outros táxons que caracterizam condições climáticas mais frias, tais como Cunoniaceae, Drymis, Ericaceae e Araucaria, não foram encontrados no registro palinológico da vereda.

\section{PALINOZONA FZU 2}

A seção sedimentar que corresponde ao intervalo de tempo que vai de 6.000 (idade interpolada) a $1.500 \pm 40$ anos AP foi caracterizada pelo predomínio de elementos arbustivos e herbáceos, diferindo da palinozona FZU 1 pelo aumento na diversidade destes elementos e pelo aparecimento de novos táxons (Senna, Gomphrena e Diplusodon). Neste período, os elementos arbustivos e herbáceos foram representados por táxons preferencialmente de formações campestres (Poaceae, Asteraceae, Rubiaceae) e de ambientes úmidos e/ ou alagados (Drosera, Eryngium, Cyperaceae e tipo Hyptis).

A palinozona FZU 2 também foi caracterizada pelo aumento da representatividade dos grãos de pólen de elementos arbóreos, incluindo a palmeira Mauritia, 
e pelo aparecimento de árvores típicas de Cerrado sentido restrito (Caryocar e Eriotheca) e de Mata de Galeria (Burseraceae), além dos táxons anteriormente identificados, Daphnopsis, tipo Butia e Podocarpus.

Os fungos e as algas apresentaram uma relação inversamente proporcional na palinozona FZU 2. Os esporos dos fungos apresentaram um acréscimo em direção ao topo do perfil, enquanto os zigósporos de algas declinaram. Esta relação pode estar relacionada ao processo de colmatação da vereda da Fazenda Urbano, ou ainda a interação ecológica de competição entre os fungos e as algas. O esporo de fungo Athelia teve ocorrência apenas nesta palinozona, sendo considerado como patógeno de líquens e algas (Kirk et al., 2001), o que poderia ter influenciado diretamente na diminuição dos zigósporos algais.

A vegetação identificada no registro polínico entre 6.000 (idade interpolada) e $1.500 \pm 40$ anos AP contém táxons comuns ao tipo fitofisionômico Campo Sujo (Poaceae, tipo Baccharis, Vernonia, tipo Hyptis, Diplusodon, Gomphrena e Eryngium), que é uma fitofisionomia arbustivo-herbácea, e ao Cerrado sentido restrito (Caryocar, Eriotheca, tipo Butia, Poaceae), que se caracteriza pela presença de árvores e subarbustos espalhados (Ribeiro \& Walter, 2008). Dessa forma, os resultados qualitativos e quantitativos dos palinomorfos sugerem que a fitofisionomia de Campo Limpo identificada na base do perfil foi substituída por um mosaico de Campo Sujo e Cerrado sentido restrito em direção ao topo do perfil.

A deposição dos sedimentos finos com matéria orgânica da vereda da Fazenda Urbano iniciou há cerca de 13.000 anos AP, no entanto, a fitofisionomia vereda senso restrito se estabeleceu somente a partir de 6.000 anos AP (idade interpolada), com o aumento de grãos de pólen de Mauritia flexuosa na seqüência sedimentar.

A ocorrência de elementos arbustivos e herbáceos, juntamente com o aumento de árvores de Cerrado e com o desenvolvimento da vereda, sugere que as condições climáticas em Buritizeiro entre 6.000 (idade interpolada) e $1.500 \pm 40$ anos AP seriam mais úmidas e quentes, com média pluviométrica anual acima de $1.000 \mathrm{~mm}$ e a duração da estação seca entre cinco e seis meses, condições estas semelhantes aos dias atuais para a região.

Dentre os principais fatores que influenciam as fitofisionomias do Cerrado, destacam-se a estacionalidade climática, a disponibilidade hídrica e as características edáficas (Felfili et al., 2001). As variações registradas nos tipos fitofisionômicos ao longo do perfil da vereda da Fazenda Urbano mostram que estes fatores, principalmente a disponibilidade hídrica, têm influenciado a dinâmica da vegetação na região de Buritizeiro desde o final do Pleistoceno.

Na Palinozona FZU 2 os sedimentos que representam o intervalo de tempo de $1.500 \pm 40$ anos aos dias de hoje foram erodidos.

\section{O PANORAMA CLIMÁTICO NO FINAL DO PLEISTOCENO E DURANTE O HOLOCENO NO CERRADO BRASILEIRO E O REGISTRO POLÍNICO DA VEREDA DA FAZENDA URBANO}

Os estudos palinológicos que visam à reconstituição das mudanças climáticas no Cerrado brasileiro durante o final do Pleistoceno (figura 7), quando houve influência da Última Glaciação sobre as floras até aproximadamente 12.000 anos AP (Salgado-Labouriau, 1994), mostram que em linhas gerais houve uma estação seca mais prolongada com temperaturas mais frias nas localidades onde as altitudes variam de 700 a $1100 \mathrm{~m}$, tais como Cromínia (GO), Lagoa dos Olhos (MG), Carajás (PA) e Águas Emendadas (DF), e condições climáticas mais úmidas e mais frias em Salitre e Lagoa de Serra Negra, no Estado de Minas Gerais (FerrazVicentini \& Salgado-Labouriau, 1996; De Oliveira, 1992; Absy et al., 1991; Barberi et al., 2000; Ledru, 1993).

Nestas localidades, no intervalo de tempo compreendido entre 19.000 e 11.500 anos AP, foram identificadas a distribuição de Cerrado arbustivo ou campo, poucas matas com árvores de clima mais frio, alguns pântanos nas depressões e ausência de veredas. (Salgado-Labouriau, 2001).

O perfil sedimentar lacustre amostrado no topo do platô em Carajás, leste da Amazônia, mostrou que após 22.800 anos AP uma fina camada argilo-arenosa rica em siderita foi depositada há aproximadamente 12.500 anos AP, sugerindo que houve um hiato na sedimentação do corpo lacustre como reflexo de condições climáticas mais secas que as atuais. $\mathrm{O}$ registro polínico de Carajás mostrou baixa concentração de grãos de pólen, representados principalmente por ervas de campos como Poaceae, Asteraceae, Borreria (Rubiaceae) e Cuphea (Lytraceae), indicando que o topo do platô estava ocupado por uma vegetação esparsa sob influência de um clima seco ou semi-árido (Absy et al., 1991).

De Oliveira (1992) com base na análise palinológica de um perfil sedimentar obtido na Lagoa dos Olhos (MG), sugeriu que entre 19.520 e 13.700 anos AP o clima era frio e semi-úmido com uma estação seca de menor duração nesta localidade. A vegetação registrada durante este intervalo de tempo era constituída por elementos de Mata de Galeria, com a ocorrência de Podocarpus, e grandes quantidades de grãos de pólen de Caryocar, uma árvore que ocorre em formações do bioma Cerrado, como o Cerrado sentido restrito e o Cerradão. Após 13.700 anos AP, a umidade diminuiu e a temperatura aumentou, sendo encontradas partículas de carvão na seqüência sedimentar, sugerindo que a vegetação sofreu a ação de queimadas naturais.

Na Lagoa de Serra Negra (MG), entre 39.930 até cerca de 14.340 anos AP, as condições climáticas eram mais úmidas e frias do que as atuais. $\mathrm{O}$ registro palinológico correspondente a este intervalo de tempo 

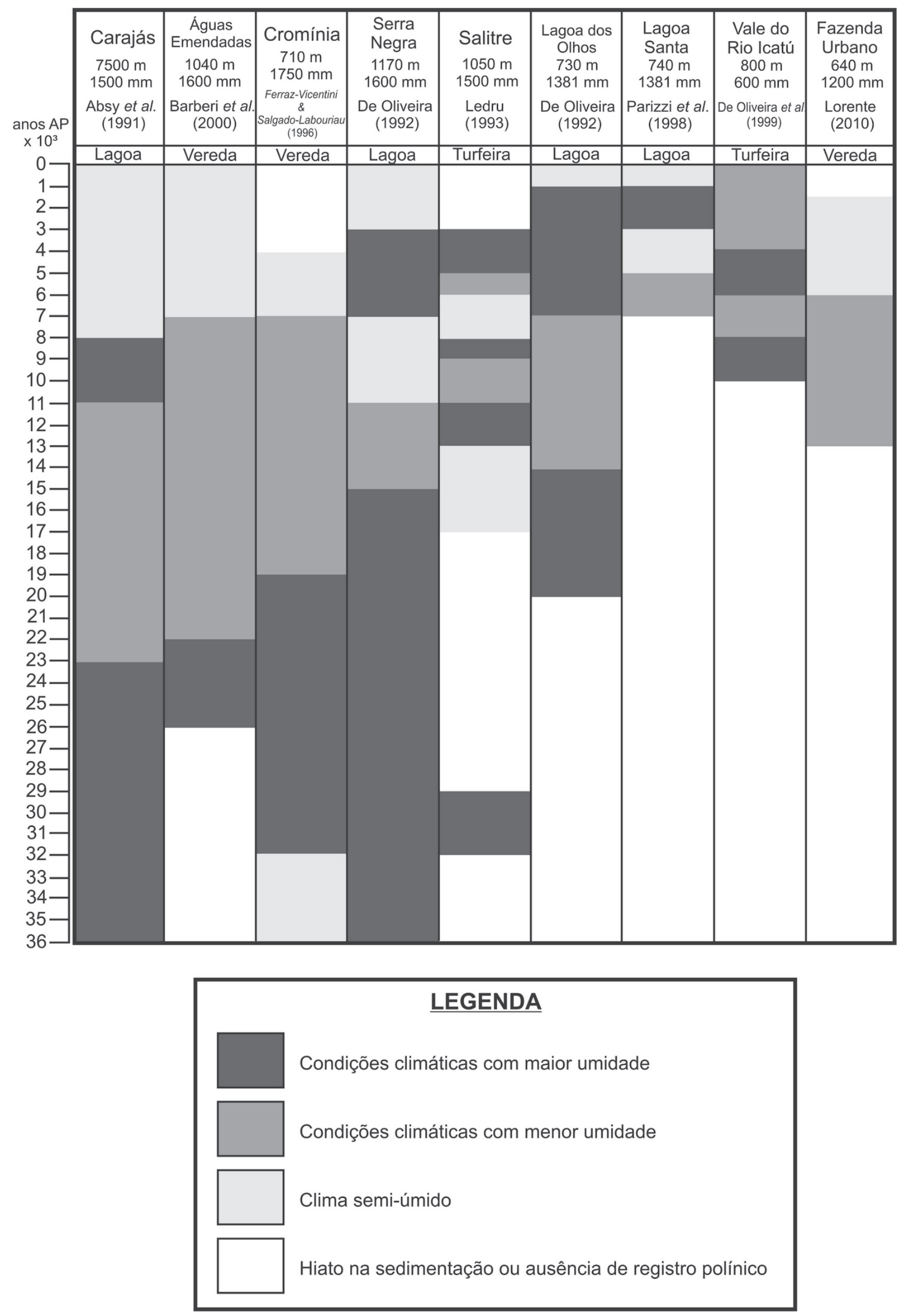

Figura 7. Comparação da seqüência das mudanças climáticas baseadas em registros polínicos no Cerrado brasileiro (modificado de Salgado-Labouriau, 1997). 
era constituído por grãos de pólen de elementos tropicais associados a elementos de vegetação de altas altitudes como Araucaria, Podocarpus, Ilex e Ericaceae. Após 14.430 anos AP os grãos de pólen dos táxons de vegetação de altas altitudes não foram registrados na seqüência sedimentar e os táxons de savana começaram a aumentar, sugerindo uma redução na precipitação pluviométrica e aumento da temperatura (De Oliveira, 1992).

O registro polínico de Salitre (MG), estudado por Ledru (1993), registrou que durante o intervalo de tempo entre 12.890 e 10.350 anos AP os grãos de pólen de Araucaria e de outros elementos associados à Floresta Ombrófila Mista, tais como Ilex, Symplocos e Drymis, estiveram presentes no registro palinológico, sugerindo que houve uma diminuição na temperatura na região durante o final do Pleistoceno, com condições de inverno prolongado. Este intervalo de tempo também foi marcado pela diminuição na concentração de elementos arbóreos, e pelo predomínio de elementos herbáceos, representados principalmente por Poaceae, Apiaceae, Mabea (Euphorbiaceae) e Ranunculus (Ranunculaceae), sugerindo condições climáticas de menor umidade.

$\mathrm{Na}$ vereda de Cromínia (GO) no período compreendido entre 18.500 e 11.300 anos AP houve uma diminuição na concentração da maioria dos palinomorfos e o pequeno corpo lacustre anteriormente formado foi substituído por um pântano circundado por gramíneas. A ausência de grãos de pólen de Mauritia, o predomínio de grãos de pólen de elementos herbáceos como Poaceae, Asteraceae e Cyperaceae, além da diminuição da maioria dos palinomorfos sugerem que no local havia uma vegetação com pouca diversidade de espécies, influenciada por condições climáticas mais secas que as atuais, semelhante e/ou comparável às descritas para regiões de clima semi-árido (FerrazVicentini \& Salgado-Labouriau, 1996).

Barberi et al. (2000) verificaram que no perfil sedimentar de uma vereda localizada no platô de Águas Emendadas (DF) houve um hiato na sedimentação entre 21.400 e 7.300 anos AP, sendo a camada orgânica substituída por uma fina camada de areia e silte. Durante este intervalo, a concentração de palinomorfos do registro palinológico alcançou os menores valores ao longo de todo o perfil, sugerindo que as condições climáticas eram mais secas que as atuais ocasionando a desertificação do platô. A vegetação na região era menos densa sob influência de um clima provavelmente semi-árido.

A análise de gases nobres em águas subterrâneas da região semi-árida no estado do Piauí, Nordeste do Brasil, permitiu estimar que a temperatura média durante o UMG foi $5^{\circ} \mathrm{C}$ mais baixa do que a temperatura média atual (Stute et al., 1995), estimando que no final do Pleistoceno as condições climáticas eram mais frias do que as atuais, concordando em linhas gerais com a diminuição das temperaturas indicadas em estudos palinológicos realizados em Minas Gerais, tais como nas localidades de Salitre, Lagoa de Serra Negra e Lagoa dos Olhos (Ledru, 1993; De Oliveira, 1992), e posteriormente registrados no Brasil Central, como em Cromínia e Águas Emendadas (Ferraz-Vicentini \& Salgado-Labouriau, 1996; Barberi et al., 2000).

No que diz respeito ao clima durante o Holoceno no bioma Cerrado (figura 7), no intervalo de tempo entre 11.000 e 7.000 anos AP, foi registrada a ocorrência de grãos de pólen de elementos da fitofisionomia Cerradão no perfil sedimentar de Lagoa Santa (MG), e de vegetação de Cerrado arbustivo em Cromínia (GO). Durante este intervalo as veredas estiveram ausentes e os pântanos e brejos secaram periodicamente sob influência de um clima quente e seco. No período de tempo entre 7.000 e 5.000 anos AP, houve uma transição entre clima seco e clima semi-úmido. A vegetação era mais densa e a precipitação pluviométrica menor do que a atual, porém com a ocorrência de chuvas torrenciais evidenciadas pelos escorregamentos em Lagoa Santa. Após 5.000 anos AP, o clima era semi-úmido, com condições de umidade semelhantes às atuais para áreas de Cerrado no Brasil, e a vegetação era composta por táxons de formações arbóreas do Cerrado, de Floresta Semidecídua e de vereda (Salgado-Labouriau, 2001).

O clima em Cromínia (GO) era mais seco do que o atual no início do Holoceno, provavelmente semiárido ou com uma longa estação seca, evidenciado pela diminuição na diversidade e na concentração dos palinomorfos no perfil sedimentar. Após 5.000 anos AP., a vegetação em Cromínia se mostrou semelhante à atual, e a vereda retornou ao local sob condições climáticas mais úmidas, sugeridas pela presença de grãos de pólen de Mauritia e de plantas de locais úmidos e/ou alagados como Cyperaceae, Drosera e Ludwigia (Salgado-Labouriau et al., 1998).

A análise palinológica de um perfil sedimentar em Lagoa Santa (MG) mostrou que a umidade aumentou entre 5.300 e 3.400 anos AP, ocorrendo à substituição do pântano por um corpo lacustre raso circundado por vegetação de Cerrado arbóreo e Mata de Galeria, sob condições climáticas mais úmidas do que durante o início do Holoceno. O clima era semelhante ao atual, quente, semi-úmido e com uma estação seca de 3 a 4 meses de duração. Entre 3.000 e 1.800 anos AP., foi observado que houve um aumento na concentração de grãos de pólen de elementos arbóreos e arbustivos de vegetação de Cerrado, tais como Stryphnodendron e Antonia, além de elementos de Floresta Semidecídua, como Callistene, Cecropia e Trema, sugerindo que a vegetação era semelhante à atual na região, e o clima era mais úmido do que no presente, com uma estação seca de menor duração (Parizzi et al., 1998).

No Vale do Rio Icatú (Médio Vale do Rio São Francisco), o clima durante o início do Holoceno foi caracterizado como frio e úmido, com o registro de táxons de florestas tropicais como Alchornea e Cecropia, e táxons de florestas de altas altitudes como Ericaceae, Rapanea e Hedyosmum. No período entre 10.540 e 6.790 anos AP os grãos de pólen de elementos de florestas de clima frio e de florestas 
tropicais diminuíram, enquanto os grãos de pólen de elementos de Caatinga e Cerrado, como Byrsonima, Mimosa, Ouratea, dentre outros, apresentaram maior representatividade, sugerindo que houve uma diminuição da umidade na região. De 6.230 a 4.240 anos AP., a vegetação e o clima desta área foram caracterizados por várias oscilações na abundância dos táxons pertencentes a diferentes formações vegetais, no entanto, este padrão mudou após 4.240 anos AP. quando os grãos de pólen dos táxons de Cerrado e de Caatinga foram mais abundantes, mostrando que a vegetação era semelhante a que ocorre atualmente no Vale do Rio Icatú (De Oliveira et al., 1999).

A análise palinológica da vereda da Fazenda Urbano permite inferir que no final do Pleistoceno, no intervalo de tempo entre $13.120 \pm 60$ e $11.640 \pm 60$ anos AP, as condições climáticas na região de Buritizeiro eram mais secas do que as atuais, condições climáticas estas semelhantes às registradas pelos estudos palinológicos nas localidades de Carajás (PA), Lagoa dos Olhos (MG), Salitre (MG), Cromínia (GO) e Águas Emendadas (DF). Embora tenha sido registrada a ocorrência de Mauritia no registro palinológico em $11.640 \pm 60$ anos AP, a vereda se estabeleceu somente a partir de 6.000 anos AP (idade interpolada) sob condições climáticas de maior umidade, semelhantes às que ocorrem atualmente em regiões de clima semi-úmido. $\mathrm{O}$ aumento da umidade e o estabelecimento da vereda após 6.000 anos (idade interpolada) em Buritizeiro, também foram verificados em outras localidades do Brasil Central, tais como Cromínia (GO) e Águas Emendadas (DF), após 7.000 anos AP, com a transição de clima seco para clima semi-úmido.

\section{CONSIDERAÇÕES FINAIS}

A análise palinológica do perfil sedimentar amostrado na vereda da Fazenda Urbano, aliada ao significado ambiental dos 51 palinomorfos identificados neste trabalho e às datações radiocarbônicas ao longo do perfil, permitiram estabelecer duas palinozonas (FZU 1 e FZU 2) que reconstituíram o paleoambiente e as condições paleoclimáticas em Buritizeiro (MG). As palinozonas estabelecidas mostram em linhas gerais que a umidade aumentou gradativamente desde o final do Pleistoceno, mais especificamente entre 13.120 \pm 60 e $1.500 \pm 40$ anos AP.

A Palinozona FZU 1 (A e B), entre $13.120 \pm 60$ e $11.640 \pm 60$ anos AP, foi caracterizada pelo predomínio de grãos de pólen de arbustos e ervas, representados principalmente por Poaceae, Asteraceae, Rubiaceae e Drosera. A fitofisionomia associada a este intervalo foi a de Campo Limpo, que se caracteriza como uma formação campestre predominantemente herbácea, com raros arbustos dispersos e ausência de árvores. Os dados palinológicos desta palinozona sugeriram que as condições climáticas durante este intervalo de tempo eram mais secas que as atuais, condições estas semelhantes ao clima semi-árido, que é caracterizado por índice pluviométrico inferior a $1.000 \mathrm{~mm}$ e por déficit hídrico de sete a oito meses.

A Palinozona FZU 2, entre 6.000 (idade interpolada) e $1.500 \pm 40$ anos AP, foi caracterizada pelo aumento de grãos de pólen de elementos arbóreos em direção ao topo da seqüência sedimentar e pelo registro de novos táxons abustivo-herbáceos e arbóreos. Neste intervalo de tempo a fitofisionomia Campo Limpo, identificada na base do perfil, foi substituída por um mosaico dos tipos fitofisionômicos Campo Sujo e Cerrado sentido restrito com a presença de árvores típicas do bioma Cerrado, tais como Caryocar e Eriotheca.

A partir de 6.000 anos AP (idade interpolada) foi registrado o aumento nos grãos de pólen de Mauritia flexuosa, sugerindo o estabelecimento da vereda como reflexo de condições climáticas mais úmidas do que as descritas para a palinozona FZU 1. A presença de Mauritia mostrou que o clima deveria ser igual ou semelhante ao semi-úmido, com índice pluviométrico acima de 1.000 mm e com estação seca com duração de cinco a seis meses, como ocorre atualmente em Buritizeiro (MG).

As condições climáticas mais secas que as atuais identificadas para a região de Buritizeiro durante o final do Pleistoceno (13.120 \pm 60 a $11.640 \pm 60$ anos AP) foram semelhantes às descritas nos registros palinológicos em outras áreas do Cerrado brasileiro no período de tempo compreendido entre 19.000 e 11.500 anos AP. O aumento da umidade e o estabelecimento da vereda da Fazenda Urbano após 6.000 anos (idade interpolada) também foram verificados em outras localidades do Brasil Central, tais como Cromínia (GO) e Águas Emendadas (DF), após 7.000 anos AP, com a transição de clima seco para clima semi-úmido.

\section{AGRADECIMENTOS}

Este trabalho foi realizado no âmbito do projeto “A evolução paleo-geo-ambiental quaternária das veredas da Bacia do Rio São Francisco, município de Buritizeiro, Minas Gerais, Brasil: geoquímica ambiental, ambiente deposicional e palinologia" com recursos do CNPq (MCT/CNPq 15/2007-Universal). $\mathrm{O}$ primeiro autor agradece a CAPES pela concessão de bolsa de mestrado.

\section{REFERÊNCIAS BIBLIOGRÁFICAS}

ABSY M.L., CLEEF A., FOURNIER M., MARTIN L., SERVANT M., SIFEDDINE A., SILVA M. F. DA., SOUBIES F., SUGUIO K., TURCQ B., VAN DER HAMMEN T. 1991. Misé em évidence de quatre phase dóuverture de la fôret dense dans Le sud-est de l'Amazonie au cours dês 60.000 dernieres années. Premiere comparaison avec dáutres régions tropicales. Comptes Rendus Academie des Sciences Paris, 312:673-678.

ALKMIM F.F. \& MARTINS-NETO M.A. 2001. A bacia intracratônica do São Francisco: arcabouço estrutural e cenários evolutivos. In: C.P. Pinto \& M.A. Martins-Neto (eds). Bacia do São Francisco: geologia e recursos naturais, Sociedade Brasileira de Geologia - MG, p.: 9-30.

BAGGIO H.B. 2008. Contribuições naturais e antropogênicas para a concentração e distribuição de metais pesados em água superficial 
e sedimento de corrente na Bacia do Rio do Formoso, município de Buritizeiro, MG. Tese de Doutorado, Instituto de Geociências, Universidade Federal de Minas Gerais, 216 p.

BARBERI M., SALGADO-LABOURIAU M.L., SUGUIO K. 2000. Paleovegetation and paleoclimate of "Vereda de Águas Emendadas", central Brazil. Journal of South American Earth Sciences, 13:241-254.

BAUERMANN S.G. 2003. Análises palinológicas e evolução paleovegetacional e paleoambiental das turfeiras de Barrocadas e Águas Claras, Planície Costeira do Rio Grande do Sul, Brasil. Tese de Doutorado, Instituto de Geociências, Universidade Federal do Rio Grande do Sul, 137 p.

CARVALHO P.G.S. 1991. As veredas e sua importância no domínio dos cerrados. Informe Agropecuário, 15:54-56.

COLINVAUX P., DE OLIVEIRA P.E., PATIÑO J.E.M. 1999 Amazon pollen manual and atlas. Harwood Academic Publ., Amsterdam, 332 pp.

DE OLIVEIRA P.E. 1992. A palynological record of Late Quaternary vegetational and climate change in southeastern Brazil. Tese de Doutorado, Ohio State University, 242 p.

DE OLIVEIRA P.E., BARRETO A.M.F., SUGUIO K. 1999. Late Pleistocene/Holocene climatic and vegetational history of the brazilian caatinga: the fossil dunes of the middle São Francisco river. Palaeogeography, Palaeoclimatology, Palaeoecology, 152:319-337.

EMBRAPA - EMPRESA BRASILEIRA DE PESQUISAS AGROPECUÁRIAS. 2008. Disponível em http://www.bdclima. cnpm.embrapa.br. Acessado em 23 nov 2008.

FAEGRI K. \& IVERSEN J. 1989. Texbook of Pollen analysis. Hafner Pub., New York, 486 pp.

FELFILI J.M., SOUSA-SILVA J.C., Scariot A. 2001. Biodiversidade, ecologia e conservação do Cerrado: avanços no conhecimento. In: A. Scariot., J.C. Sousa-Silva \& J.M. Felfili (eds.) Cerrado: ecologia, biodiversidade e conservação, Ministério do Meio Ambiente, p.: 27-44

FERRAZ-VICENTINI K.R. \& SALGADO-LABOURIAU M.L. 1996. Palynological analysis of a palm swamp in Central Brazil. Journal of South American Earth Sciences, 9:207-219.

FERREIRA M.B. 1980. O cerrado em Minas Gerais: gradações e composição florística. Informe Agropecuário, 61:4-8.

GONZÁLEZ V. 1987. Los morichales de lo Llanos orientales. Un enfoque ecológico. Corpoven, Caracas, $35 \mathrm{pp}$.

GRIMM E.C. 1987. CONISS: a fortran 77 program for stratigraphically constrained cluster analysis by method of the incremental sum of the squares. Pergamon Journal, 13:13-35.

HEINECK C.A., LEITE C.A.S., SILVA M.A DA., VIEIRA V.S. 2003 Mapa Geológico do Estado de Minas Gerais. Convênio COMIG/ CPRM, 1 mapa geológico, escala 1:1.000.000

IEF - INSTITUTO ESTADUAL DE FLORESTAS 2008. Mapeamento da Cobertura Vegetal e Uso do Solo do Estado de Minas Gerais. Disponível em http://www.ief.mg.gov.br. Acessado em 12 abr 2008.

KINGSTON D.R., DISHROON C.P., WILLIAMS P.A. 1983. Global basin classification system. The American Association of Petroleum Geologists Bulletin, 67:2175-2193.

KIRK P.M. CANNON P.F., WINTER D.W., STALPERS J. 2001. Dictionary of the fungi. CABI Publishing, Wallingford, $655 \mathrm{pp}$.

LEDRU M-P. 1993. Late Quaternary environmental and climatic changes in Central Brazil. Quaternary Research, 39:90-98.

LORENTE F.L. 2010. Análise palinológica da vereda da Fazenda Urbano, município de Buritizeiro, Minas Gerais, Brasil. Dissertação de Mestrado, Instituto de Geociências, Universidade Federal de Minas Gerais, 59 p.

LORENZI H. 1996. Palmeiras no Brasil: nativas e exóticas. Plantarum, Nova Odessa, 303 pp.

MARCHANT R., ALMEIDA L., BEHLING H., BERRIO J.C., BUSH M., CLEEF A., DUIVENVOORDEN J., KAPPELLE M., DE OLIVEIRA P.E., OLIVEIRA-FILHO A.T., LOZÁNOGARCIA S., HOOGHIEMSTRA H., LEDRU M-P., LUDLOWWIECHERS B., MARKGRAF V., MANCINI V., PAEZ M., PRIETO A., RANGEL O., SALGADO-LABOURIAU M.L. 2002. Distribution and ecology of parent taxa of pollen lodged within the Latin American pollen database. Review of Palaeobotany and Palynology, 121:1-75.
MELO D.R de. 2008. Evolução das veredas sob impactos ambientais nos geossistemas planaltos de Buritizeiro, MG. Tese de Doutorado, Instituto de Geociências, Universidade Federal de Minas Gerais, 341 p.

MENDONÇA R.C., FELFILI J.M., WALTER B.M.T., SILVA JÚNIOR M.C DA., REZENDE A.V., FILGUEIRAS T.S., NOGUEIRA P.E. 2008. Flora vascular do bioma Cerrado. In: S.M. Sano., S.P. de Almeida., J.F. Ribeiro (eds.). Cerrado: ecologia e flora, Embrapa Informação Tecnológica, 2, p.: 4231279.

PARIZZI M.G., KOHLER H.C., SALGADO-LABOURIAU M.L. 1998. Genesis and environmental history of Lagoa Santa, southeastern Brazil. The Holocene, 8:311-321.

REATTO A. \& MARTINS E. DE S. 2001. Classes de solo em relação aos controles da paisagem do bioma Cerrado. In: A. Scariot., J.C. Sousa-Silva., J.M. Felfili (eds.) Cerrado: ecologia, biodiversidade e conservação, Ministério do Meio Ambiente, p.: 49-59.

RIBEIRO J.F. \& WALTER B.M.T. As principais fitofisionomias do bioma Cerrado. In: S.M. Sano., S.P. de Almeida., J.F. Ribeiro (eds.). Cerrado: ecologia e flora, Embrapa Informação Tecnológica, 1, p.: 151-199.

SALGADO-LABOURIAU M.L. \& RULL V. 1986. A method of introducing exotic pollen for paleoecological analysis of sediments. Review Palaeobotany and Palynology, 47:97-103.

SALGADO-LABOURIAU M.L. 1973. Contribuição à palinologia dos Cerrados. Academia Brasileira de Ciências, Rio de Janeiro, $291 \mathrm{pp}$.

SALGADO-LABOURIAU M.L. 1994. História Ecológica da Terra. $2^{\mathrm{a}}$ ed. Edgard Blücher, São Paulo, $307 \mathrm{pp}$.

SALGADO-LABOURIAU M.L. 1997. Late Quaternary palaeoclimate in the savannas of South America. Journal of Quaternary Science, 12:371-379.

SALGADO-LABOURIAU M.L., BARBERI M., FERRAZVICENTINI K.R., PARIZZI M.G. 1998. A dry climatic event during the late Quaternary of tropical Brazil. Review of Palaeobotany and Palynology, 99:115-129.

SALGADO-LABOURIAU M.L. 2001. Reconstruindo as comunidades vegetais e o clima no passado. Humanidades, 48:24-40.

SILVA C.I. DA. 2009. Distribuição espaço-temporal de recursos florais utilizados por espécies de Xylocopa (Hymenoptera, Apidae) e interação com plantas do cerrado sentido restrito no triângulo mineiro. Tese de Doutorado, Universidade Federal de Uberlândia, 283p.

SOUZA V.C. \& LORENZI H. 2005. Botânica Sistemática. Instituto Plantarum, São Paulo, 608 pp.

STUTE M., FORSTER M., FRISCHKORN H., SEREJO A., CLARK J.F., SCHLOSSER P., BROECKER W.S., BONANI G. 2005. Cooling of Tropical Brazil ( 5 degrees C) during the Last Glacial Maximum. Science, 269:379-383.

TRYON R.M. \& TRYON A.F. 1982. Ferns and allied plants with special reference to tropical America. Springer-Verlag, New York, $857 \mathrm{pp}$.

TYSON R.V. 1995. Sedimentary Organic Matter: Organic Facies and Palynofacies. Chapman \& Hall, London, 615pp.

VAN GEEL B. 1978. A paleoecological study of Holocenepeat bog section in Germany and the Netherlands. Review of Palaeobotany and Palynology, 25:1-120.

YBERT J-P., SALGADO-LABOURIAU M.L., BARTH O.M., LORSCHEITTER M.L., BARROS M.A. DE., CHAVES S.A. DE M., LUZ C.F.P. DA., RIBEIRO M., SCHEEL R., VICENTINI K.F. 1992. Sugestões para padronização da metodologia empregada em estudos palinológicos do Quaternário. Revista Instituto de Geociências, 13:47-49 